\title{
Fuel Savings from Hybrid Electric Vehicles
}

\section{Technical Report} NREL/TP-540-42681

March 2009

K. Bennion and M. Thornton
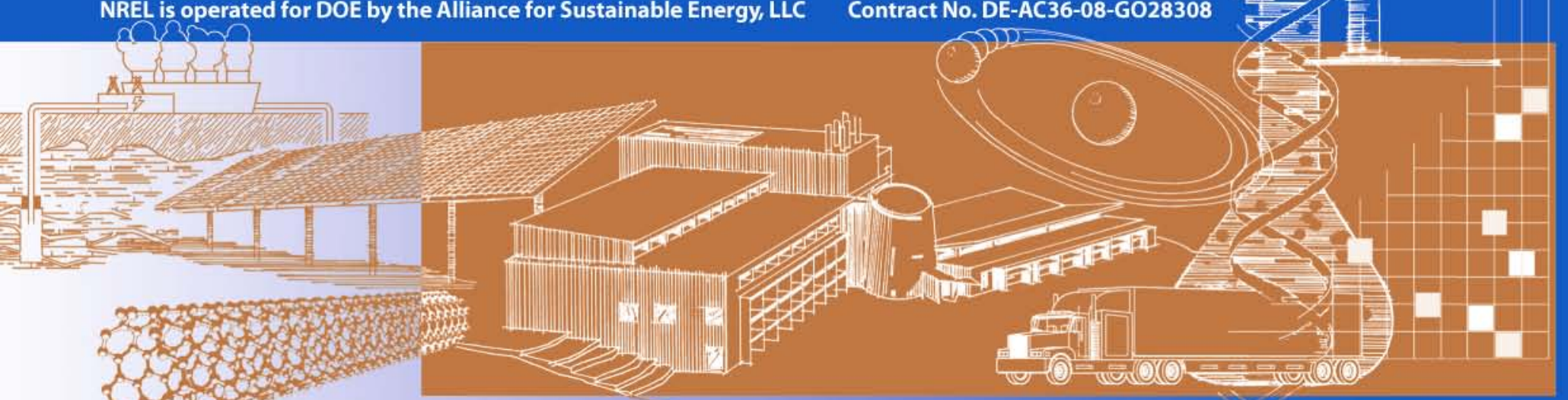


\section{Fuel Savings from Hybrid Electric Vehicles}

K. Bennion and M. Thornton

Prepared under Task No. FC08.2000

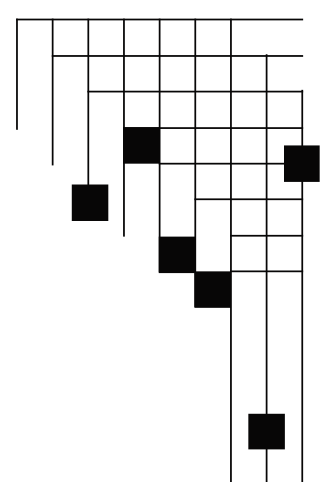

National Renewable Energy Laboratory

1617 Cole Boulevard, Golden, Colorado 80401-3393

303-275-3000 • www.nrel.gov

NREL is a national laboratory of the U.S. Department of Energy

Office of Energy Efficiency and Renewable Energy

Operated by the Alliance for Sustainable Energy, LLC

Contract No. DE-AC36-08-GO28308 


\section{NOTICE}

This report was prepared as an account of work sponsored by an agency of the United States government. Neither the United States government nor any agency thereof, nor any of their employees, makes any warranty, express or implied, or assumes any legal liability or responsibility for the accuracy, completeness, or usefulness of any information, apparatus, product, or process disclosed, or represents that its use would not infringe privately owned rights. Reference herein to any specific commercial product, process, or service by trade name, trademark, manufacturer, or otherwise does not necessarily constitute or imply its endorsement, recommendation, or favoring by the United States government or any agency thereof. The views and opinions of authors expressed herein do not necessarily state or reflect those of the United States government or any agency thereof.

Available electronically at http://www.osti.gov/bridge

Available for a processing fee to U.S. Department of Energy and its contractors, in paper, from:

U.S. Department of Energy

Office of Scientific and Technical Information

P.O. Box 62

Oak Ridge, TN 37831-0062

phone: 865.576 .8401

fax: 865.576 .5728

email: mailto:reports@adonis.osti.gov

Available for sale to the public, in paper, from:

U.S. Department of Commerce

National Technical Information Service

5285 Port Royal Road

Springfield, VA 22161

phone: 800.553.6847

fax: 703.605.6900

email: orders@ntis.fedworld.gov

online ordering: http://www.ntis.gov/ordering.htm 


\section{Acknowledgments}

The authors would like to acknowledge the programmatic support of the Vehicle Technologies Program in the U.S. Department of Energy's Office of Energy Efficiency and Renewable Energy. 


\section{Executive Summary}

Along with the rapid rise of gasoline prices since 2002 has come a renewed interest in energy costs and energy security. Of particular concern is the impact on the transportation sector and light-duty vehicles (LDVs). The dependence of LDVs on petroleum contributes to personal and national economic concerns, and the nation's dependence on oil imports impacts our trade imbalance and energy security. For these reasons, it is essential to reduce petroleum use in LDVs.

Hybrid electric vehicles (HEVs) have the potential to reduce both petroleum usage and greenhouse gas emissions in the United States. For this reason, many individuals, corporations, and government groups have shown considerable interest in these vehicles since they were first introduced into the U.S. market in 1999. Quantifying their fuel-savings benefit places the impacts of HEVs in a context that allows them to be compared with other technologies proposed for reducing our reliance on oil imports in the transportation sector.

This type of analysis also provides a framework for comparing the benefits of alternative technologies in terms of incentives. Although a few earlier studies have included an evaluation of fuel savings from HEVs, the analysis described in this report provides the cumulative historical benefit of these vehicles in terms of their fuel savings.

The analysis described here is based on estimated fuel savings from new HEV sales, annual vehicle stocks or fleets, and cumulative totals. The results show that, since they first entered the U.S. market, HEVs have saved nearly 385 million gallons, or over 9 million barrels, of fuel. Although these fuel savings are small in comparison to the total amount of fuel consumed in the United States by light-duty vehicles ( 8.86 million barrels per day), the savings will increase as additional HEVs penetrate the market, adding annually to the baseline of fuel savings from existing HEVs.

The results of this analysis indicate that, although HEVs are relatively new to the U.S. market, they could significantly reduce the amount of oil imported for use in light-duty vehicles. However, to increase the fuel reduction impact of LDVs, individuals must reverse past trends and switch from larger vehicles to smaller, more fuel efficient vehicles, including HEVs. For individuals who require the functionality of large cars, minivans, sport utility vehicles, and light-duty trucks, the availability of HEV models could provide significant fuel use reductions.

While interest in HEVs is growing, work on the next technology breakthrough is needed not only to improve vehicle efficiency but also to enable energy diversification for vehicle transportation. By improving vehicle efficiency and enabling energy diversification, the nation could achieve significant reductions in fuel use for transportation. However, achieving this goal will require immediate action. 


\section{Table of Contents}

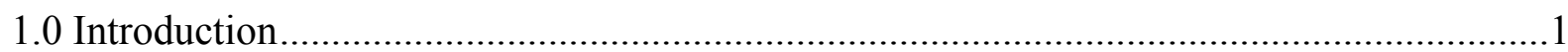

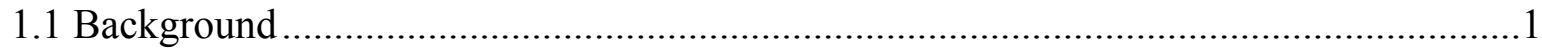

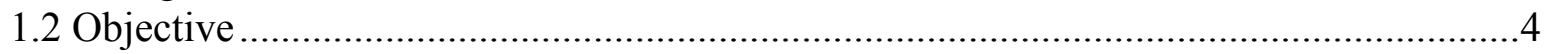

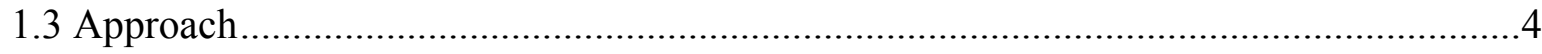

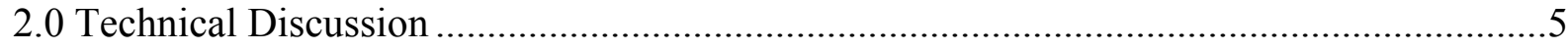

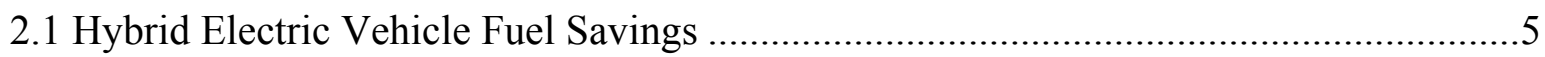

2.2 Fuel Reduction Impact..........................................................................................

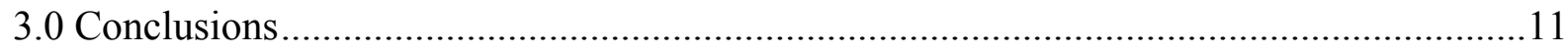

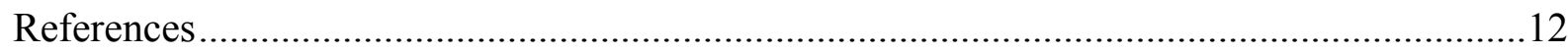

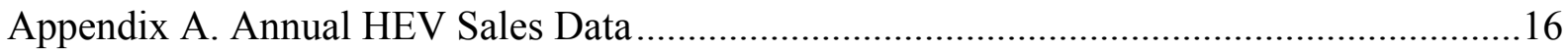

Appendix B. Comparison Vehicles and Fuel Economy ……...................................................18

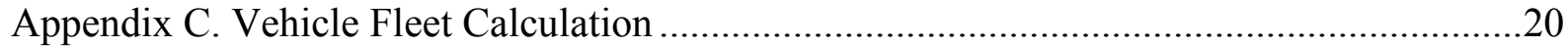

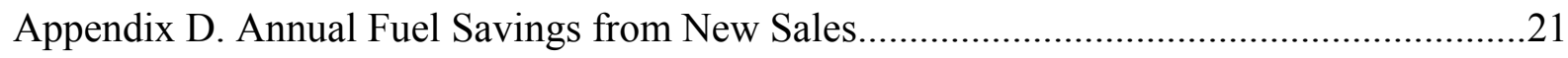

Appendix E. Annual Fuel Savings from Vehicle Fleet ...........................................................22

Appendix F. Cumulative Fuel Savings by Year ....................................................................23 


\section{List of Figures}

Figure 1. Regular unleaded gasoline average retail price, 1976-8/2008 ..................................1

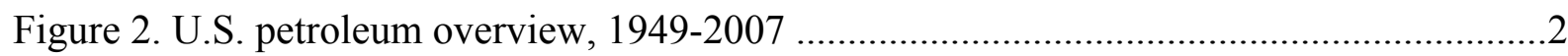

Figure 3. Value of crude oil imports, 1973-2007 .................................................................2

Figure 4. 2007 petroleum consumption by sector...................................................................

Figure 5. 2006 transportation petroleum use by type ………................................................

Figure 6. Sales-weighted fuel savings - new HEV sales........................................................6

Figure 7. Fleet-weighted fuel savings - annual HEV fleet...................................................6

Figure 8. Fleet-weighted cumulative fuel savings ……………............................................

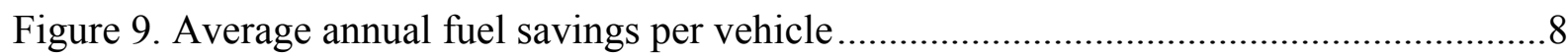

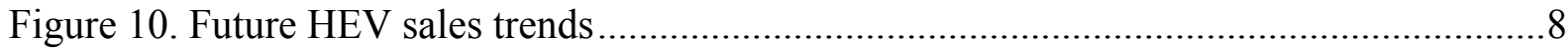

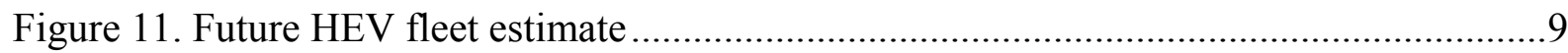

Figure 12. Fleet annual fuel savings as percentage of U.S. LDV fleet.....................................10

Figure 13. Fuel consumption vs. fuel economy ……………................................................

Figure 14. Transportation petroleum use trends ...................................................................11

Figure A-1. HEV sales and annual percent increase [Source: Table A-1] ..............................16

\section{List of Tables}

Table 1. Example of Fuel Consumption vs. Fuel Economy Improvements ..............................11

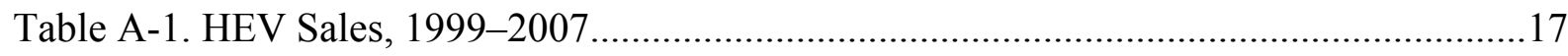

Table B-1. Comparison Vehicles and Fuel Economy Estimates ...............................................18

Table B-2. Fuel Economy or Fuel Consumption Benefit ........................................................19

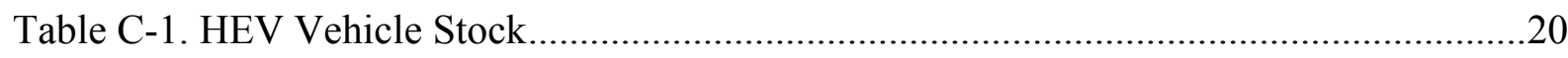

Table D-1. Fuel Savings from New HEV Sales (thousands of gallons).....................................21

Table E-1. Annual HEV Vehicle Stock Fuel Savings (thousands of gallons)...........................22

Table F-1. Cumulative HEV Fuel Savings (thousands of gallons)............................................23 


\subsection{Introduction}

\subsection{Background}

Along with the rapid rise of gasoline prices since 2002 has come a renewed interest in energy costs and energy security. This concern was highlighted in President George W. Bush's 2006 State of the Union address [1] in which he said, "Keeping America competitive requires affordable energy. And here we have a serious problem: America is addicted to oil, which is often imported from unstable parts of the world." However, this concern related to energy is not new. In 1979, President Jimmy Carter said, "This intolerable dependence on foreign oil threatens our economic independence and the very security of our nation. The energy crisis is real. It is worldwide. It is a clear and present danger to our nation. These are facts and we simply must face them" [2]. Each of these comments occurred during times of high gasoline prices. Figure 1 compares the average annual nominal price and the inflation-adjusted (real) price of a gallon of regular unleaded gasoline since 1976. In 2007, the average real price approached values not seen since the late 1970s and early 1980s. The average monthly fuel prices in 2008 show an even steeper rate of increase. This rise in the cost of gasoline impacts both the individual and national economy.

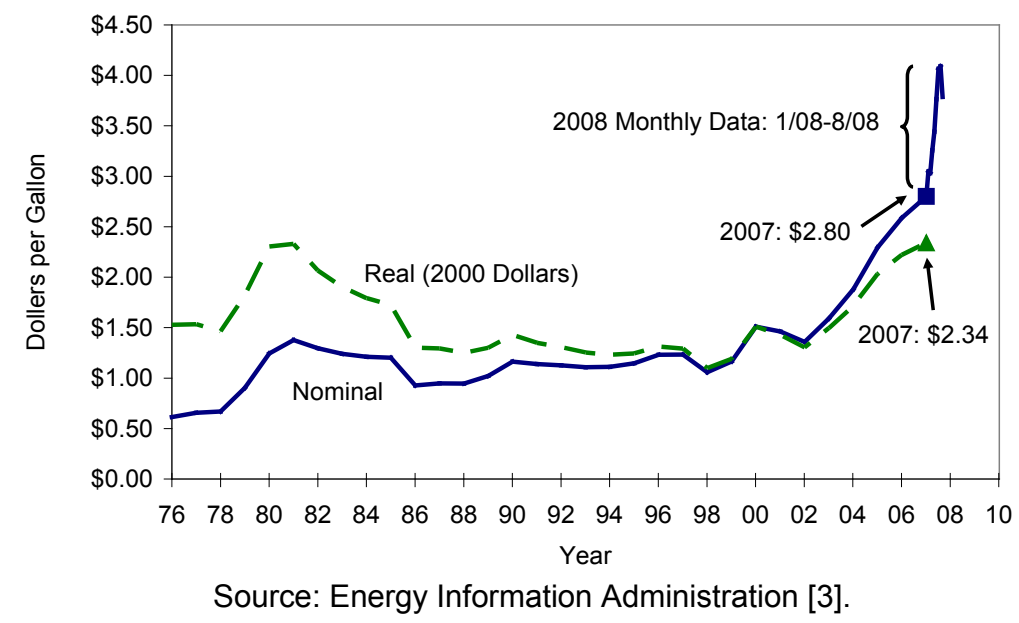

Figure 1. Regular unleaded gasoline average retail price, 1976-August 2008

Concerns related to petroleum use extend beyond the cost of a gallon of gasoline and personal finances, however. Along with the overall upward trend in petroleum consumption has come a similar upward trend in petroleum imports, as shown in Figure 2. In 2007, net imports amounted to 12 million barrels per day, according to the Energy Information Administration [3]. This is roughly equivalent to 10 Exxon Valdez oil tankers per day ${ }^{1}[4,5]$. In 2007, imported oil amounted to 58\% of petroleum consumption. By comparison, in 1979, at the time of President Carter's Crisis of Confidence speech, imports accounted for $43 \%$ of total consumption $[2,3]$. This increasing reliance on oil imports affects the energy security of the United States, as noted by Presidents Carter and Bush.

\footnotetext{
${ }^{1}$ The Exxon Valdez was carrying more than 1.2 million barrels of oil at the time of the oil spill in Alaska in $1989[4,5]$.
} 


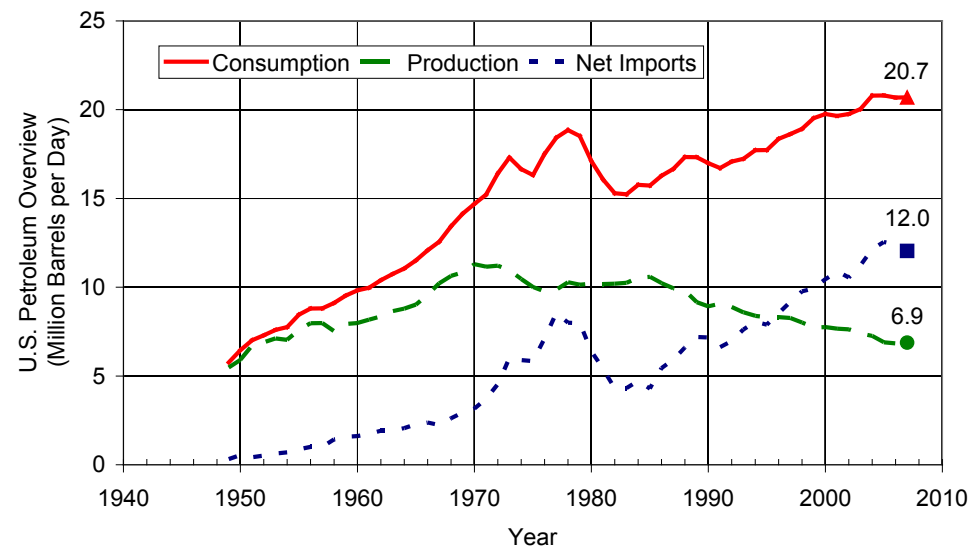

Source: Energy Information Administration [3].

Figure 2. U.S. petroleum overview, 1949-2007

Our increasing reliance on imported petroleum not only affects energy security, it also impacts our economy and trade imbalance. According to the Energy Information Administration, the cost of oil imports in 2007 approached \$246 billion (nominal dollars) [3]. This is equivalent to about $\$ 674$ million per day, or $\$ 468,000$ per minute throughout 2007. The rapid rise in this cost over time is highlighted in Figure 3.

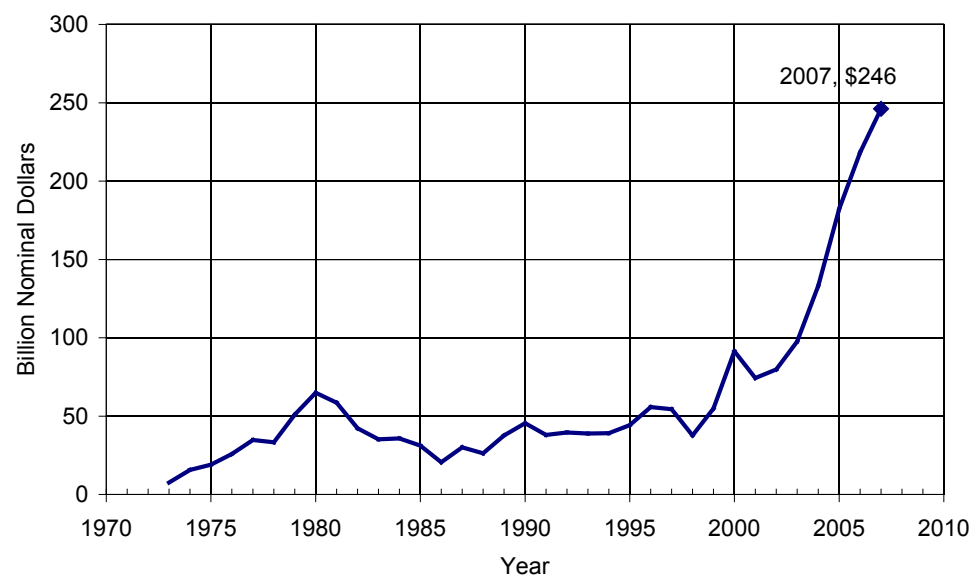

Source: Energy Information Administration [3].

Figure 3. Value of crude oil imports, 1973-2007

Concerns related to personal finances, national security, and the overall economy are particularly important in relation to transportation. The transportation sector is dependent on petroleum. In 2007, 14.26 million barrels per day, or $69 \%$ of total petroleum consumption, went to the transportation sector [3]. Comparisons to other sectors of petroleum use are shown in Figure 4. 


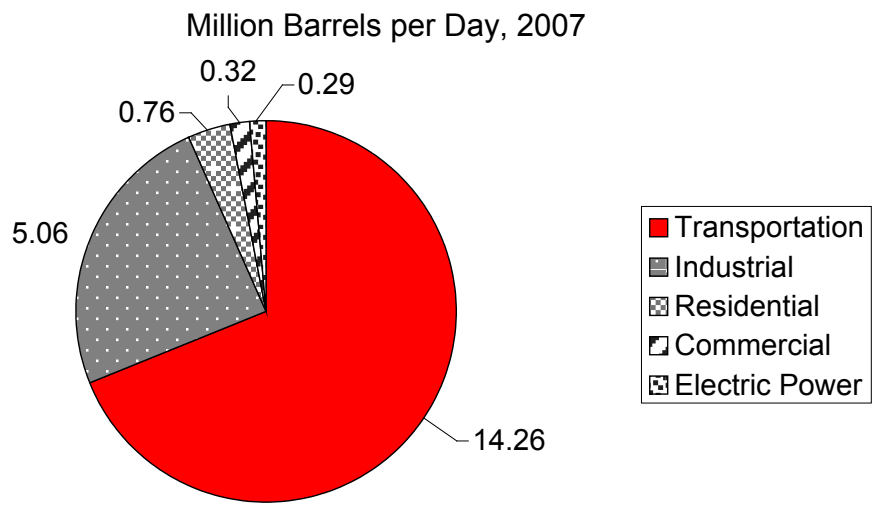

Source: Energy Information Administration [3].

Figure 4. 2007 petroleum consumption by sector

Looking at where the petroleum goes in the transportation sector indicates the impact of light-duty vehicles (LDVs). These include cars, sport utility vehicles (SUVs), and light trucks. In 2006, 8.86 million barrels per day were used for light-duty vehicles [6]. Fuel use by light-duty vehicles was significantly higher than that of any other segment, as illustrated in Figure 5. Developing a long-term solution to our energy needs requires reducing the petroleum consumption of LDVs in the United States. Reductions in petroleum use could possibly come from changes in consumer behavior, increases in energy efficiency, or greater diversification of energy sources.

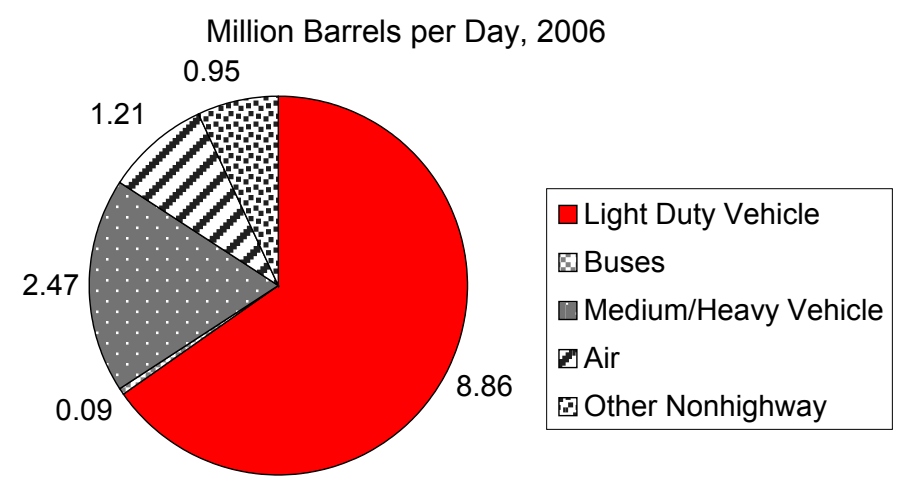

Source: Transportation Energy Data Book, Edition 27 [6].

Figure 5. 2006 transportation petroleum use by type

A relatively recent development for reducing fuel use in vehicles or improving their overall operating efficiency is the introduction of hybrid electric vehicles (HEVs) into the marketplace. Since HEVs were first introduced in the United States in 1999, interest in them has grown, and so has their acceptance as a viable means of reducing fuel use in the U.S. transportation sector. The number of models available has increased significantly since 1999, and according to recent announcements by vehicle manufacturers, the choices are likely to grow. Renewed public interest in rising fuel prices and the environment-e.g., global warming issues - has also helped to promote hybrids as manufacturers and government groups alike take on a "greener" image. Many municipalities, state governments, and federal 
agencies have adopted tax incentives or other benefits, such as access to commuter lanes, to promote the use of HEVs.

Much of the public's interest in HEVs springs from these vehicles' potential to reduce overall vehicle fuel use. According to the U.S. Environmental Protection Agency (EPA), a vehicle uses only a small fraction of the energy available in gasoline to operate. The remaining energy is lost through inefficiency or losses within the system [7]. Although HEVs could decrease the nation's overall vehicle fuel use, some manufacturers have used HEV technology to boost vehicle performance instead of fuel economy in some of their models.

Hybrid electric vehicles reduce fuel use by focusing on three areas. First, they allow the use of a smaller engine that can run in the most efficient part of its operating range. This is enabled through the electric drive system as it adjusts the required load on the engine. Also, some HEV models can be driven in all-electric mode when the power required to drive the vehicle is low, thus preventing the engine from having to run inefficiently at low loads. Second, HEVs prevent the engine from operating when it is unnecessary, such as when idling or when the vehicle is stopped. Finally, hybrids can store some of the kinetic energy normally lost while braking. In HEVs, batteries store some of this kinetic energy and then release it to assist the gasoline engine, as needed.

\subsection{Objective}

Because many individuals, corporations, and government groups have shown considerable interest in hybrid electric vehicles, it is important to quantify the fuel-savings benefit of HEVs since they were first introduced into U.S. markets. Quantifying that benefit places the impacts of HEVs in a context that allows them to be compared with other technologies proposed to decrease our reliance on oil imports for transportation. In addition, this type of analysis provides a framework for comparing the benefits of alternative technologies according to incentives for promoting them. Although a few previous studies have considered fuel savings from HEVs $[8,9]$, this analysis provides the cumulative historical benefit of HEVs in terms of their fuel savings.

\subsection{Approach}

The first step in the analysis involved collecting and verifying HEV sales data since the vehicles first entered the U.S. market. No one source was found that contains a complete list of annual sales by year for each type of HEV available at the time of this analysis, so we used multiple data sources to collect the required information [10-18]. Multiple sources were also used to verify the accuracy of the sales data [19-45]. The collected sales data are listed in Table A-1 of Appendix A.

After we compiled a list of HEVs available in the marketplace, our next task involved identifying conventional vehicles for comparison. The method used in this analysis assumed that an HEV replaced a similar type of conventional vehicle made by the same manufacturer. It did not look at the benefits that can be gained when consumers change to a different class of vehicle altogether, such as from an SUV to a car. Because the intent of the analysis was to determine the potential benefits of hybridization, hybrids were compared only with nonhybrids of the same or similar models. Table B-1 in Appendix B lists the conventional vehicles used in the analysis with the respective HEVs. 
A vehicle's fuel economy depends on its type and the operator's driving style, so it is difficult to create a general fuel economy value for a given vehicle. To judge both HEVs and conventional vehicles consistently, we used both new and old EPA label estimates for this analysis. The old EPA limits were based on EPA tests for 2007 and earlier model-year vehicles. They were limited to two test cycles for city and highway driving. The new EPA tests began with 2008 model-year vehicles, and they include additional tests to reflect higher speeds, colder temperatures, and air-conditioning use [46]. For comparison, fuel economy values reported by users were also considered in the analysis. Table B-1 lists the fuel economy estimates used for the analysis, while Table B-2 lists the percent improvement in fuel economy.

To calculate the cumulative benefits of hybrids, it was necessary to focus on the total number of HEVs in use each year (i.e., the annual HEV vehicle stock) rather than on only new HEV sales. Total HEV sales would have provided an approximate number for the total stock, but the actual vehicle stock would be expected to be smaller because vehicles periodically go out of service. For this reason, a vehicle stock model was used to account for the reduction in the vehicle stock over time as a result of accidents or other factors. Total vehicle stock estimates thus relied on Argonne National Laboratory's VISION model to account for vehicles that go out of service over time [47]. The VISION model is an Excel-based tool that contains a vehicle stock calculation for predicting future vehicle trends (see Appendix C, Equation C1).

Applying Equation C-1 to the HEV sales data collected resulted in the vehicle stock estimates shown in Table $\mathrm{C}-1$. The results are grouped by brand for comparison. Based on these estimates, there were more than 1 million HEVs on the road or in use at the end of 2007. This is slightly fewer than the total number of vehicle sales to take into account vehicles that were no longer in service because of accidents or for other reasons. All three fuel economy estimates were fed into the fuel savings calculations. The calculations included fuel savings from new vehicle sales, annual vehicle stock, and cumulative totals. The results assumed that all vehicles in a given year were sold at the beginning of the year, since annual sales data were used. In addition to fuel savings totals, efforts were made to highlight potential fuel savings from today's current HEV mix.

\subsection{Technical Discussion}

\subsection{Hybrid Electric Vehicle Fuel Savings}

The HEV fuel savings data included estimates for three different fuel-displacement metrics. The first involved the fuel savings from new HEV sales in a given year. This estimate relied on the HEV sales data that were collected. Total fuel savings from new vehicle sales would have provided an approximation for the total annual fleet or vehicle stock fuel savings. However, this would have overestimated fuel savings, since some vehicles went out of service. For this reason, the vehicle stock estimates (Appendix C) were used to determine total fleet fuel savings in a given year. Cumulative fleet fuel savings by year were also calculated to determine cumulative fuel savings from HEVs. Fuel savings depend on the assumed vehicle miles traveled (VMT) in one year. This analysis used a fixed VMT of 
12,240 miles for each metric. This was based on data from the Transportation Energy Data Book, which lists total vehicle registrations and total vehicle miles traveled up to 2006 [6].

Fuel savings from new HEV sales through 2007 are shown in Figure 6. One can see that in 2007, new HEV sales contributed to fuel savings of about 56 million gallons of gasoline, or 1.3 million barrels of oil, based on the new EPA fuel economy measures. The results in Figure 6 show that the results obtained using the different fuel economy estimates are comparable with the new EPA label showing the largest benefit. Appendix D lists the equation used for the analysis and tabulated results based on the new EPA fuel economy estimates. The fuel savings of 1.3 million barrels over all of 2007 represent $15 \%$ of the petroleum consumed by LDVs in a single day.

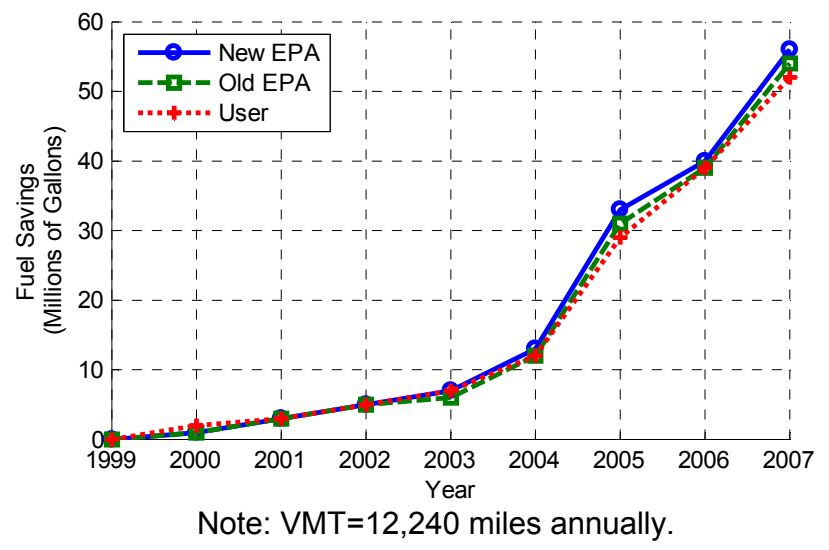

Figure 6. Sales-weighted fuel savings - new HEV sales

Annual vehicle stock or fleet fuel savings included fuel savings from all HEVs in use for a given year. Equation E-1 in Appendix E shows the method used to determine fuel savings for HEVs on the road, and results are provided in Table E-1 for new EPA estimates. According to Table E-1, the total HEV vehicle fleet in 2007 saved more than 158 million gallons of fuel. Figure 7 shows that the results are comparable across all of the vehicle fuel economy estimates. As with the analysis based on new sales, the new EPA results are higher. The fuel savings of 158 million gallons, or 3.8 million barrels, represent $44 \%$ of the petroleum consumed by LDVs in a single day.

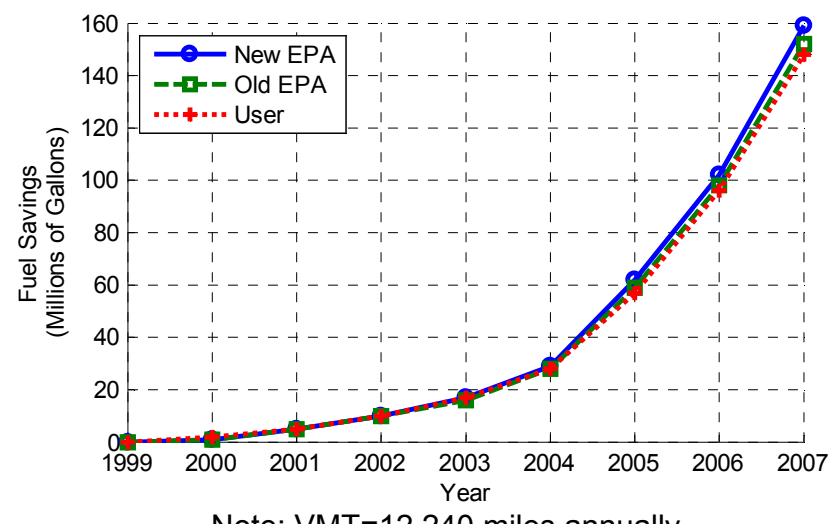

Note: VMT=12,240 miles annually.

Figure 7. Fleet-weighted fuel savings - annual HEV fleet 
Cumulative fuel savings up to a given year included the cumulative sum of each year's fleet or vehicle stock fuel savings, as highlighted in Equation F-1. Table F-1 lists cumulative fuel savings based on the new EPA fuel economy estimates. Through 2007, HEVs have saved over 385 million gallons of fuel. Figure 8 compares the fuel savings from all the fuel economy estimates. The fuel savings of 385 million gallons, or 9.2 million barrels, are about equal to the amount of petroleum consumed by LDVs in a single day.

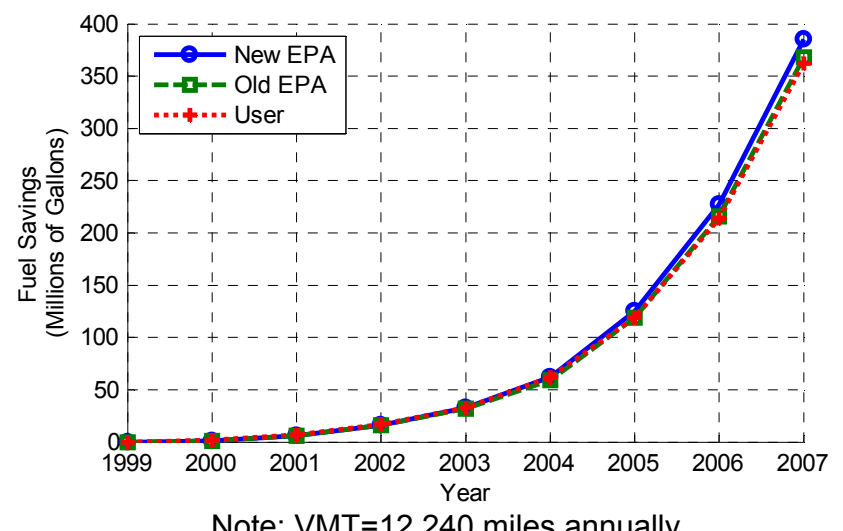

Figure 8. Fleet-weighted cumulative fuel savings

\subsection{Fuel Reduction Impact}

Although fuel savings from HEVs are small in relation to the national statistics for fuel consumption mentioned earlier, that is a result of the small number of HEVs currently in use in the United States. Assuming that approximately 235 million cars and trucks are in use in the United States [6], the 1 million HEVs in use represent only about $0.4 \%$ of all U.S. lightduty vehicles. This leads to the following question: What would be the impact of increasing the penetration of HEVs in the marketplace?

To answer the question, we first assumed that the HEV offerings remained similar to those that were sold in 2007. Next, we calculated the average sales-weighted fuel savings per HEV per year, as shown in Equation 1.

$$
F=M\left[\frac{\sum_{j=1}^{n}\left(\frac{S_{j}}{M P G_{j}^{C V}}\right)}{\sum_{j=1}^{n} S_{j}}-\frac{\sum_{j=1}^{n}\left(\frac{S_{j}}{M P G_{j}^{H E V}}\right)}{\sum_{j=1}^{n} S_{j}}\right],
$$

where

$\begin{aligned} j & =\text { index to unique HEV (e.g., an Insight or Prius) } \\ n & =\text { number of unique HEVs } \\ S & =\text { vehicles sold of type } j \text { in desired year } \\ M & =\text { annual vehicle miles traveled in year } \\ M P G^{C V} & =\text { conventional vehicle fuel economy } \\ M P G^{H E V} & =\text { HEV fuel economy. }\end{aligned}$


The results from Equation 1 are shown in Figure 9, and they are based on past sales. As seen in Figure 9, the sales-weighted average fuel savings per vehicle were almost 160 gallons per year in 2007. This value was used as an estimate for projected future vehicle fuel savings. It assumes the future HEV fleet is comparable to the vehicles sold in 2007.

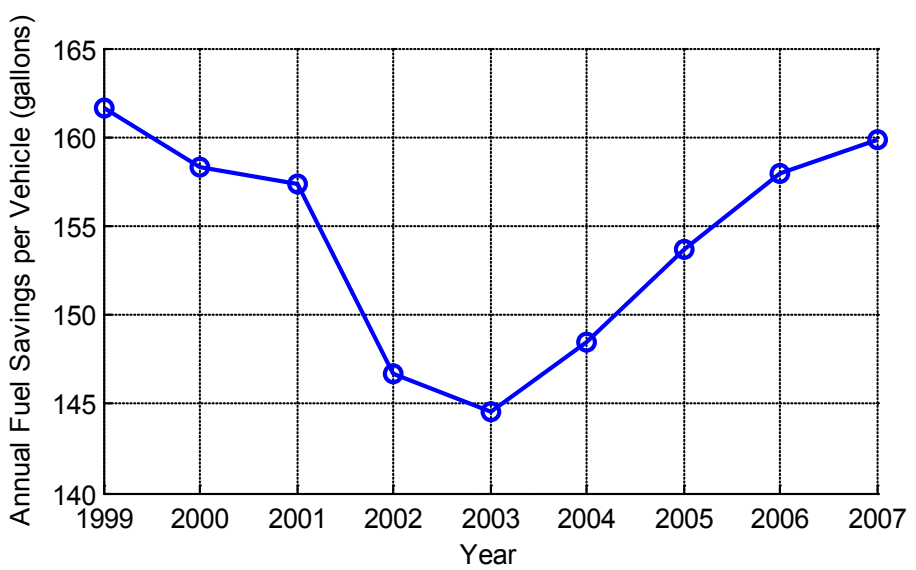

Note: VMT=12,240 miles annually, and average fuel savings were calculated from new HEV sales-weighted fuel consumption.

Figure 9. Average annual fuel savings per vehicle

The next step required an estimate of future sales of HEVs per year. HybridCARS published a report [48] that compared multiple HEV sales forecasts from various sources and noted the variability of the estimates. It also compared the forecasts to a trend line based on HEV sales from 2000 through 2005. This trend is shown in Figure 10 by the green dashed line. This trend was used by researchers at the University of California, Davis (UC Davis) in their estimates of potential HEV fuel savings [8]. Figure 10 also shows the sales trend, including sales data from 2006 and 2007, which is indicated by the solid red line. We used this updated sales trend line for future HEV sales projections.

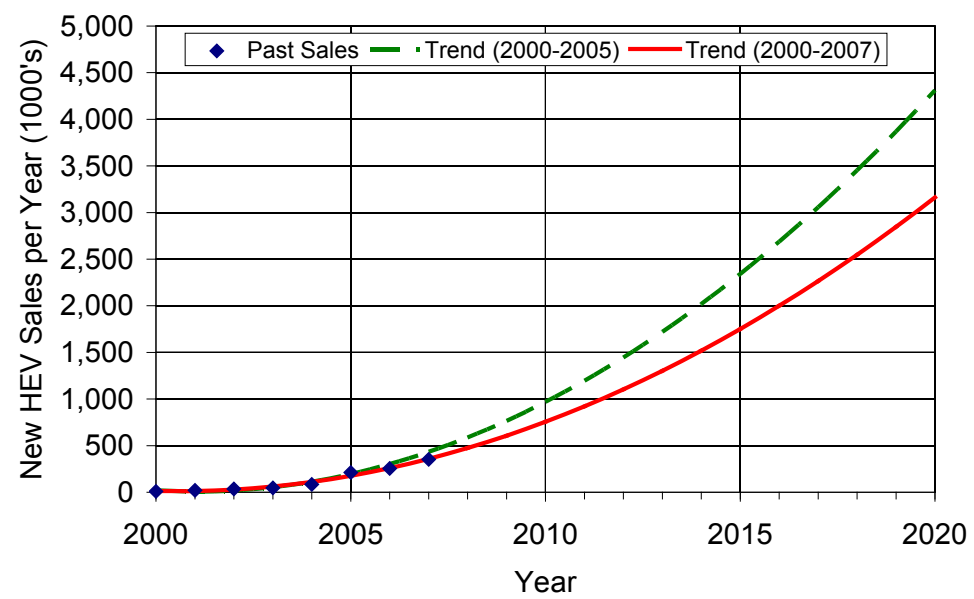

Figure 10. Future HEV sales trends 
The next step required estimating the projected size of the HEV vehicle fleet. As in the previous analysis, we could have used the cumulative sales totals; instead, we used the vehicle stock calculations listed in Appendix C. The vehicle stock equations were applied to the projected future vehicles sales based on sales from 2000 through 2007. The results are shown in Figure 11. The left vertical axis shows the projected HEV fleet size, in millions of vehicles; the right vertical axis shows the fleet size as a percentage of the total LDV fleet, which was fixed at 235 million light-duty vehicles.

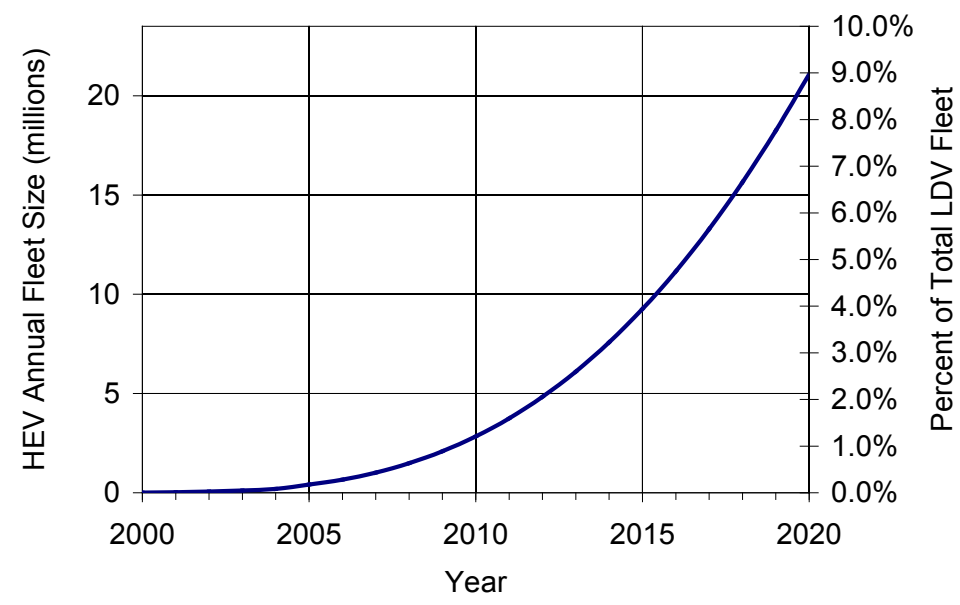

Assumptions: 235 million LDVs [6]; 2000-2007 HEV sales trend.

Figure 11. Future HEV fleet estimate

The projected future HEV fleet fuel savings were calculated by using the HEV vehicle stock estimates above and the average 160 gallons saved per year per vehicle from Figure 9. The results are shown in Figure 12. The annual fuel savings are shown against the percentage of HEVs in the LDV fleet. The right vertical axis also shows the fuel savings as a percentage of total LDV fuel consumption. The figure highlights the effect of the current HEV fleet, along with projections to 2010, 2015, and 2020 .

The analysis done by UC Davis also estimated potential fuel savings from HEVs, and the results of their analysis are shown for comparison [8]. They estimated that in $2010 \mathrm{HEVs}$ will replace $1.2 \%$ of conventional LDVs, resulting in a fuel savings of $0.4 \%$. They also estimated the fuel savings if HEVs reach $10 \%$ of the LDV fleet, which is shown on the graph for comparison. The results are similar, given the different methodologies. The primary intent of this analysis is not to predict the future, but to highlight the challenges related to reducing LDV fuel use. 


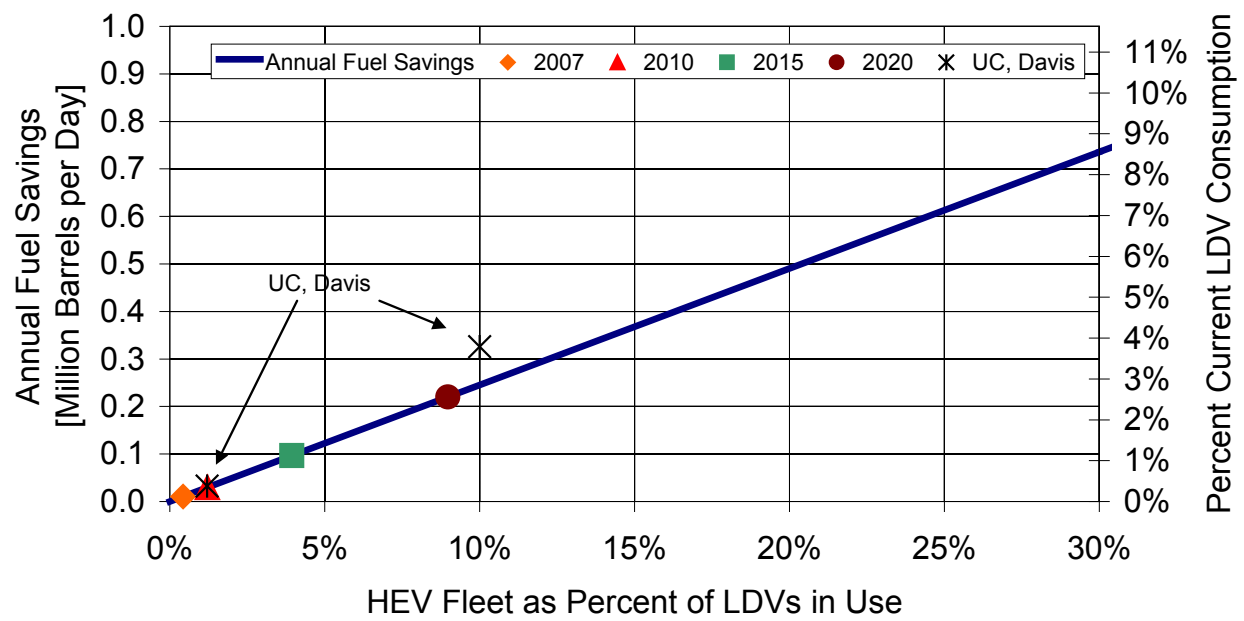

Assumptions: 235 million LDVs [6]; LDV fuel use of 8.86 million barrels per day [6]; fuel saving of 160 gallons per year per vehicle.

Figure 12. Fleet annual fuel savings as percentage of U.S. LDV fleet

Figures 11 and 12 show that HEVs can save a large amount of fuel as they penetrate more of the market. However, their overall impact in comparison to the total amount of fuel used by LDVs is limited if they are used only to replace comparable compact or midsize conventional vehicles that may already have relatively high fuel economy. Extending HEVs further into other vehicle segments would increase the slope of the line in Figure 12, and lead not only to increased fuel savings per vehicle but also to increased market penetration. This can be done if people switch from SUVs and light trucks to smaller cars, which could have HEV powertrains. Fuel savings would increase if HEV technology were applied to larger vehicles for consumers who require the functionality of a larger vehicle.

The relative benefit of switching to a different vehicle segment type or to hybridizing SUVs or light trucks is highlighted in Figure 13. The figure shows the nonlinear relationship between fuel economy and fuel consumption for two example vehicles. Table 1 highlights two vehicle options that assume the same hybridization fuel economy benefit of $40 \%$ with an annual VMT of 12,240 miles. The base fuel economy is considered to be that of a conventional vehicle, while the new fuel economy could be the result of hybridization.

The fuel savings are the total annual gallons of fuel saved annually by switching to the same type of vehicle but with improved fuel economy. As shown in Figure 13 and Table 1, vehicle A has a lower base fuel economy but shows a significantly higher fuel savings benefit for the same percentage increase in fuel economy.

To significantly reduce fuel use, then, any or all of the following alternatives are needed. The first involves switching from larger vehicles to smaller, more fuel efficient vehicles that could also include those that use HEV powertrains. Second, for those who need the functionality of larger vehicles, the use of HEV powertrains could provide significant fuel savings per vehicle because of the higher overall fuel consumption of the larger vehicles. The final option is to continue switching smaller vehicles to HEVs. This change would reduce the large increase in petroleum use by larger vehicles that has been occurring over the last few decades, as illustrated in Figure 14. 
Consumption vs. MPG

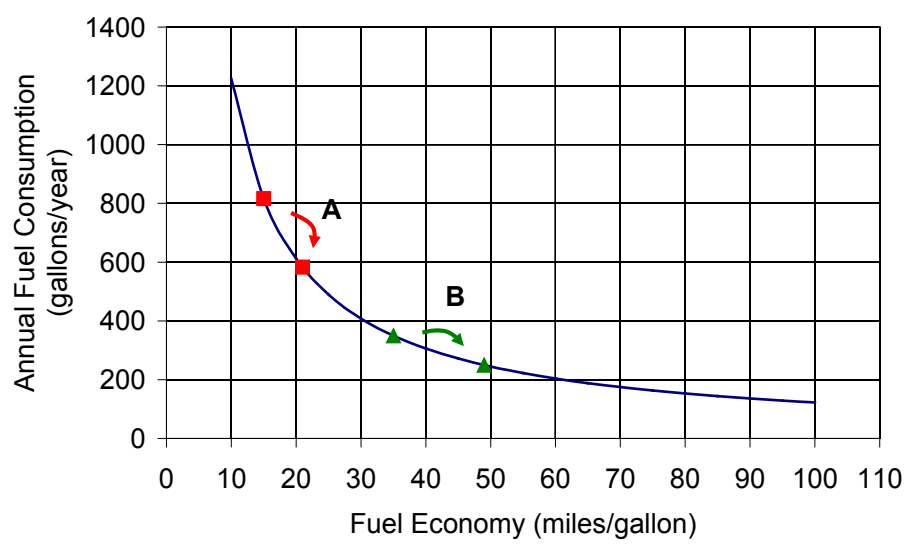

Figure 13. Fuel consumption vs. fuel economy

Table 1. Example of Fuel Consumption vs. Fuel Economy Improvements

\begin{tabular}{ccccc}
\hline \hline Vehicle & $\begin{array}{c}\text { Base Fuel } \\
\text { Economy } \\
{[\mathrm{mpg}]}\end{array}$ & $\begin{array}{c}\text { New Fuel Economy } \\
{[\mathrm{mpg}]}\end{array}$ & $\begin{array}{c}\text { Fuel } \\
\text { Economy } \\
\text { Improvement }\end{array}$ & $\begin{array}{c}\text { Annual Fuel } \\
\text { Savings } \\
\text { [gallons] }\end{array}$ \\
\hline $\mathrm{A}$ & 15 & 21 & $40 \%$ & 233 \\
$\mathrm{~B}$ & 35 & 49 & $40 \%$ & 100 \\
\hline \hline
\end{tabular}

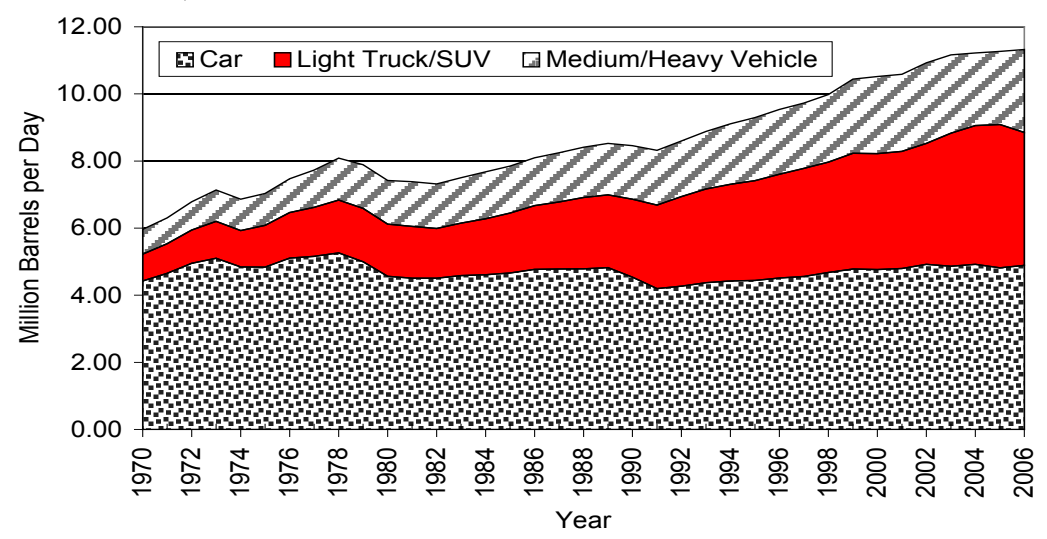

Sources: Transportation Energy Data Book 26, Tables A.1, A.5, and A.6. [49]; DOT FHWAY Highway Statistics 2006, Table vm-1 [50].

Figure 14. Transportation petroleum use trends

\subsection{Conclusions}

Although HEVs are relatively new to the U.S. market, they have the potential to significantly reduce the amount of oil we import for use in light-duty vehicles. Since they were introduced into U.S. markets, HEVs have saved nearly 385 million gallons, or 9.2 million barrels, of 
fuel. Although these savings are small in comparison to the total amount of oil consumed by light-duty vehicles in the United States, fuel savings will increase as HEVs penetrate more areas of the market.

To increase the impact in fuel reduction for LDVs, consumers must reverse past trends and switch from larger vehicles to smaller, more fuel-efficient vehicles, which could include HEVs. For consumers who require the functionality of large cars, minivans, SUVs, and lightduty trucks, the availability of HEV models could provide significant reductions in fuel use.

While interest in HEVs is growing, work on the next technology breakthrough is needed to not only improve vehicle efficiency but also to enable energy diversification for vehicular transportation. Through improvements in vehicle efficiency and energy diversification, significant reductions in fuel use for transportation are possible, but this will require immediate action. This change in vehicle fuel economy will take time. The question is, will this change take place before the next energy crisis?

\section{References}

1. Bush, G. "President George W. Bush's Address before a Joint Session of the Congress on the State of the Union." January 31, 2006. Available at www.cspan.org/executive/transcript.asp?cat=current_event\&code=bush_admin\&year $=2006$.

2. Carter, J. “Crisis of Confidence.” July 15, 1979. Available at www.pbs.org/wgbh/amex/carter/filmmore/ps_crisis.html.

3. Energy Information Administration. “Annual Energy Review 2007.” Available at www.eia.doe.gov/aer/contents.html.

4. Exxon Valdez Oil Spill Trustee Council. Available at www.evostc.state.ak.us/facts/index.cfm.

5. Exxon Valdez Oil Spill Trustee Council. "Frequently Asked Questions About the Spill.” Available at www.evostc.state.ak.us/History/FAQ.cfm.

6. Davis, S.; Diegel, S. Transportation Energy Data Book, Edition 27. Oak Ridge, TN: Oak Ridge National Laboratory, 2008.

7. U.S. Department of Energy and U.S. Environmental Protection Agency. "Advanced Technologies \& Energy Efficiency." Available at www.fueleconomy.gov/feg/atv.shtml.

8. Turrentine, T.; Delucchi, M.; Heffner, R.; Kurani, K.; Sun, Y. "Quantifying the Benefits of Hybrid Vehicles." UCD-ITS-RR-06-17. Davis, CA: Institute of Transportation Studies, University of California, Davis, Nov. 15, 2006. 
9. Johnson, C.; Bergeron, P. Fuel Use Metrics. Golden, CO: National Renewable Energy Laboratory, Sept. 2006.

10. InsightCentral.net. "Sales Statistics." Available at www.insightcentral.net/KB/sales.html.

11. ToyoLand. "Toyota Prius Chronological History." Available at www.toyoland.com/prius/chronology.html.

12. U.S. Department of Energy. "Historical U.S. Hybrid Sales." Available at www.eere.energy.gov/vehiclesandfuels/facts/2007_fcvt_fotw462.html.

13. Energy Futures, Inc. Hybrid Vehicles, Vol. 7, No. 6; Dec. 2005.

14. Green Car Congress. "U.S. Hybrid Sales Crest 10,000 in December.” Available at www.greencarcongress.com/2005/01/us_hybrid_sales.html.

15. Electric Drive Transportation Association (EDTA). "Hybrid Vehicle Sales Information and Tax Credits." Available at www.electricdrive.org/index.php?tg=articles\&idx=Print\& topics $=7 \&$ article $=692$.

16. Energy Futures, Inc. Hybrid Vehicles, Vol. 9, No. 1; Feb. 2007.

17. HybridCARS. Available at www.hybridcars.com/market-dashboard/dec06-ussales.html.

18. U.S. Department of Energy, Alternative Fuels \& Advanced Vehicles Data Center. "HEV Sales by Model." May 28, 2008. Available at http://afdc.energy.gov/afdc/data/vehicles.html.

19. Green Car Congress. "Hybrid Sales 1H04: Some Surprises." July 1, 2004. Available at www.greencarcongress.com/2004/07/hybrid_sales_1h.html.

20. Green Car Congress. “August Hybrid Sales: Some Decline.” Sept. 3, 2004. Available at www.greencarcongress.com/2004/09/august_hybrid_s.html.

21. Green Car Congress. "October 04 U.S. Hybrid Sales.” Nov. 3, 2004. Available at www.greencarcongress.com/2004/11/october_04_us_h.html.

22. Green Car Congress. "Toyota's Hybrid Sales Total 280,000+." Nov. 1, 2004. Available at www.greencarcongress.com/2004/11/toyotarsquos_hy.html.

23. Green Car Congress. "US Hybrid Sales Crest 10,000 in December.” Jan. 4, 2005. Available at www.greencarcongress.com/2005/01/us_hybrid_sales.html.

24. Green Car Congress. "Hybrids Up 81\% in 2004; California Leads Nation with 30\%." Apr. 25, 2005. Available at www.greencarcongress.com/2005/04/hybrids_up_81_i.html. 
25. Green Car Congress. "February US Hybrid Sales Second-Strongest Ever." Mar. 1, 2005. Available at www.greencarcongress.com/2005/03/february_us_hyb.html.

26. Green Car Congress. "US Hybrid Sales Rocket Upward in March.” Apr. 1, 2005. Available at www.greencarcongress.com/2005/04/us_hybrid_sales.html.

27. Green Car Congress. "April Hybrid Sales in US More than Triple from Year Before, Almost Reach 21,000.” May. 3, 2005. Available at www.greencarcongress.com/2005/05/april_hybrid_sa.html.

28. Green Car Congress. "US Hybrid Sales in May Up 2.3x from 2004; Sales Pace Drops from April 05." June 1, 2005. Available at www.greencarcongress.com/2005/06/us_hybrid_sales.html.

29. Green Car Congress. "Hybrid Sales Increase in June from May; Highlander Off to Strong Start." July 1, 2005. Available at www.greencarcongress.com/2005/07/hybrid_sales_in.html.

30. Green Car Congress. "US Hybrid Sales Hit All-Time Monthly High in August." Sept. 1, 2005. Available at www.greencarcongress.com/2005/09/us_hybrid_sales.html.

31. Green Car Congress. "Hybrid Sales in US Top 205,000 in 2005." Jan. 4, 2006. Available at www.greencarcongress.com/2006/01/hybrid_sales_in.html.

32. Green Car Congress. "January 2006 US Hybrid Sales Almost Double from Prior Year." Feb. 23, 2006. Available at www.greencarcongress.com/2006/02/january_2006_us.html.

33. Green Car Congress. "February 2006 US Hybrid Sales Up 44\% from Prior Year; Prius Down 7.5\%." Mar. 7, 2006. Available at www.greencarcongress.com/2006/03/february_2006_u.html.

34. Green Car Congress. "Hybrid Sales in US Climbed 7.5\% in March." Apr. 5, 2006. Available at www.greencarcongress.com/2006/04/hybrid_sales_in.html.

35. Green Car Congress. "US Hybrid Sales in April Back Over 21,000; Second Highest Month Yet (updated)." May 2, 2006. Available at www.greencarcongress.com/2006/05/us_hybrid_sales.html.

36. Green Car Congress. "Ford's US Hybrid Sales More than Double in April." May 2, 2006. Available at www.greencarcongress.com/2006/05/fords_us_hybrid.html.

37. Green Car Congress. "Sales of Hybrids in US Hit New Peak in May." June 1, 2006. Available at www.greencarcongress.com/2006/06/sales_of_hybrid.html.

38. Green Car Congress. "US Sales of Hybrids Stay Strong in June 2006, Up 20\% from 2005." July 3, 2006. Available at www.greencarcongress.com/2006/07/us_sales_of_hyb.html. 
39. Green Car Congress. “Prius Passes 500,000 Sales Mark Worldwide.” June 7, 2006. Available at www.greencarcongress.com/2006/06/prius_passes_50.html.

40. Green Car Congress. "US Sales of Hybrids Top 25,000 Units in July for a New High.” Aug. 4, 2006. Available at www.greencarcongress.com/2006/08/us_sales_of_hyb.html.

41. Green Car Congress. "US Sales of Hybrids Hit New High in August: 26,189 Units, $1.8 \%$ of LDV Market." Sept. 6, 2006. Available at www.greencarcongress.com/2006/09/us_sales_of_hyb.html.

42. Green Car Congress. "US Sales of Hybrids Drop in September. Oct. 4, 2006. Available at www.greencarcongress.com/2006/10/us_sales_of_hyb.html.

43. Green Car Congress. "US Sales of Hybrids in October Up 11\% Year-on-Year." Nov. 3, 2006. Available at www.greencarcongress.com/2006/11/us_sales_of_hyb.html.

44. Green Car Congress. "US Sales of Hybrids in November Up 13.8\% Year-on-Year." Dec. 6, 2006. Available at www.greencarcongress.com/2006/12/us_sales_of_hyb.html.

45. Green Car Congress. "Sales of Hybrids in the US Up 24\% in December; Up 22\% in 2006 (corrected)." Jan. 4, 2007. Available at www.greencarcongress.com/2007/01/sales_of_hybrid.html.

46. U.S. Department of Energy and U.S. Environmental Protection Agency. "New MPG Ratings.” Available at www.fueleconomy.gov/feg/ratings2008.shtml.

47. Argonne National Laboratory. VISION 2006 AEO Model. Argonne, IL: Argonne National Laboratory. Available at www.transportation.anl.gov/software/VISION/index.html.

48. HybridCARS. "Hybrid Market Forecasts." Available at www.hybridcars.com/hybriddrivers/hybrid-market-forecasts.html.

49. Davis, S.; Diegel, S. Transportation Energy Data Book, Edition 26. Oak Ridge, TN: Oak Ridge National Laboratory, 2007.

50. U.S. Department of Transportation Federal Highway Administration, "Highway Statistics 2006." Available at www.fhwa.dot.gov/policy/ohim/hs06/htm/vm1.htm. 


\section{Appendix A. Annual HEV Sales Data}

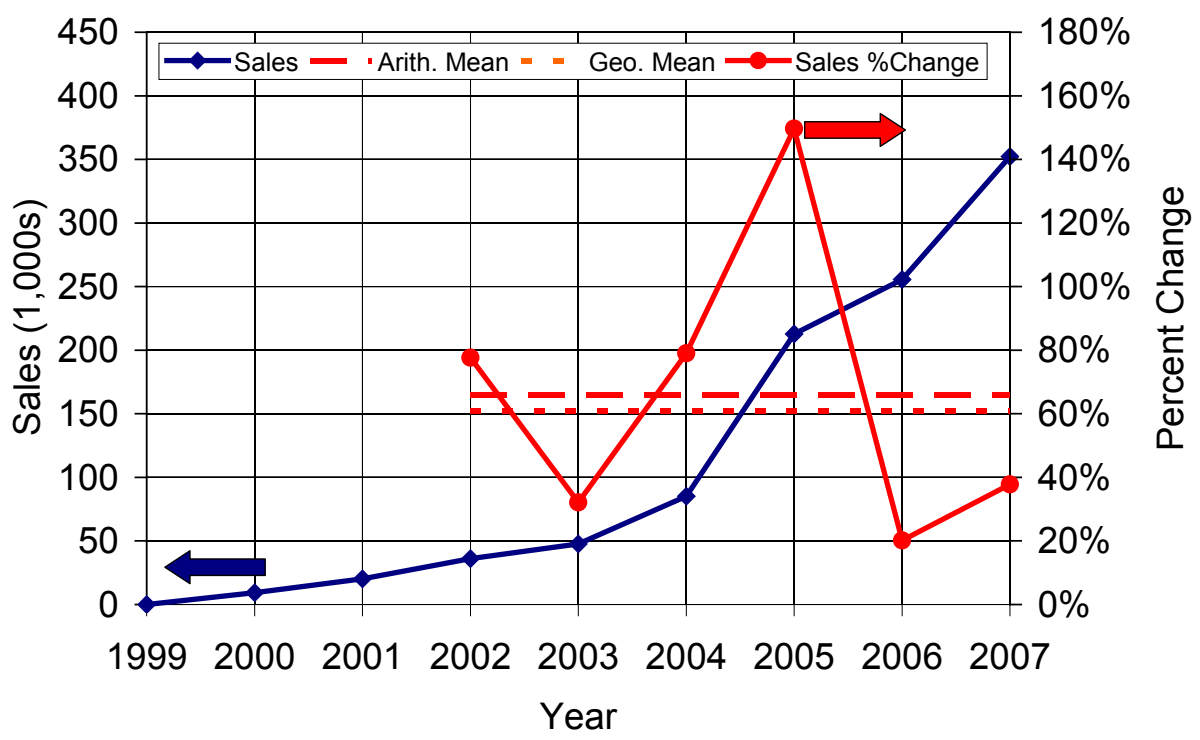

Figure A-1. HEV sales and annual percent increase [Source: Table A-1] 
Table A-1. HEV Sales, 1999-2007

\begin{tabular}{|c|c|c|c|c|c|c|c|c|c|c|c|}
\hline Brand & Vehicle & 1999 & 2000 & 2001 & 2002 & 2003 & 2004 & 2005 & 2006 & $2007^{[18]}$ & $\begin{array}{l}\text { Grand } \\
\text { Total }\end{array}$ \\
\hline \multirow[t]{2}{*}{ Ford } & Escape & & & & & & $2,993^{[14]}$ & $18,797^{[15]}$ & $20,149[17]$ & 21,386 & 63,325 \\
\hline & Mariner & & & & & & & $998^{[15]}$ & $3,174^{[17]}$ & 3,722 & 7,894 \\
\hline Ford Total & & & & & & & 2,993 & 19,795 & 23,323 & 25,108 & 71,219 \\
\hline \multirow[t]{3}{*}{ GM } & Aura & & & & & & & & & 772 & 772 \\
\hline & Sierra(a) & & & & & & $1,000^{[13]}$ & $3,000^{[16]}$ & $3,000^{[b]}$ & & 7,000 \\
\hline & Vue & & & & & & & & & 4,403 & 4,403 \\
\hline GM Total & & & & & & & 1,000 & 3,000 & 3,000 & 5,175 & 12,175 \\
\hline \multirow[t]{3}{*}{ Honda } & Accord & & & & & & $1,061^{[13]}$ & $16,826^{[15]}$ & $5,598[17]$ & 3,405 & 26,890 \\
\hline & Civic & & & & $13,700^{[12]}$ & $21,800^{[12]}$ & $25,571^{[13]}$ & $25,864^{[15]}$ & $31,251^{[17]}$ & 32,575 & 150,761 \\
\hline & Insight & $17^{[10]}$ & $3,788^{[10]}$ & $4,726^{[10]}$ & $2,216^{[10]}$ & $1,20^{[12]}$ & $583^{[13]}$ & $666^{[15]}$ & $722^{[17]}$ & & 13,918 \\
\hline Honda Total & & 17 & 3,788 & 4,726 & 15,916 & 23,000 & 27,215 & 43,356 & 37,571 & 35,980 & 191,569 \\
\hline Nissan & Altima & & & & & & & & & 8,388 & 8,388 \\
\hline Nissan Total & & & & & & & & & & 8,388 & 8,388 \\
\hline \multirow[t]{6}{*}{ Toyota } & Camry & & & & & & & & $31,341^{[17]}$ & 54,477 & 85,818 \\
\hline & GS 450h & & & & & & & & $1,784[17]$ & 1,645 & 3,429 \\
\hline & Highlander & & & & & & & $17,989^{[16]}$ & $31,485^{[17]}$ & 22,052 & 71,526 \\
\hline & LS 600hL & & & & & & & & & 937 & 937 \\
\hline & Prius & & $5,562^{[11]}$ & $15,556^{[11]}$ & $20,119[11]$ & $24,600[12]$ & $53,991^{[13]}$ & $107,897^{[15]}$ & $106,971[17]$ & 181,221 & 515,917 \\
\hline & $\mathrm{RX} 400 \mathrm{~h}$ & & & & & & & $20,674^{[16]}$ & $20,161^{[17]}$ & 17,291 & 58,126 \\
\hline Toyota Total & & & 5,562 & 15,556 & 20,119 & 24,600 & 53,991 & 146,560 & 191,742 & 277,623 & 735,753 \\
\hline Grand Total & & 17 & 9,350 & 20,282 & 36,035 & 47,600 & 85,199 & 212,711 & 255,636 & 352,274 & $1,019,104$ \\
\hline
\end{tabular}

Notes: (a) GM Sierra data include Chevrolet Silverado data.

(b) The GM Sierra total for 2006 was estimated on the basis of 2005 data, since published data were unavailable at the time of the analysis. 


\section{Appendix B. Comparison Vehicles and Fuel Economy}

Three sources were used for the hybrid electric vehicle fuel economy estimates. The first two estimates were based on both the new and the old EPA window labels; the third included user-reported fuel economy values. All estimates were obtained from information on EPA's Web site, www.fueleconomy.gov, at the time of this analysis [46].

Table B-1 lists the combined city and highway EPA fuel economy estimates used in the analysis. Some user-reported values were based on a small number of users. For this reason, values obtained from fewer than five users are noted in the table. If no user-reported data were available at the time of the analysis, $85 \%$ of the old EPA combined rating was selected as the user-reported value.

Table B-1. Comparison Vehicles and Fuel Economy Estimates

\begin{tabular}{|c|c|c|c|c|c|c|c|c|}
\hline \multirow[b]{2}{*}{ Brand } & \multirow[b]{2}{*}{ Vehicle } & \multirow[b]{2}{*}{$\begin{array}{c}\text { Conventional } \\
\text { Comparison Vehicle }\end{array}$} & \multicolumn{3}{|c|}{ HEV } & \multicolumn{3}{|c|}{ Conventional Comparison Vehicle } \\
\hline & & & $\begin{array}{c}\text { User- } \\
\text { Reported }\end{array}$ & $\begin{array}{l}\text { Old EPA } \\
\text { Combined }\end{array}$ & $\begin{array}{l}\text { New EPA } \\
\text { Combined }\end{array}$ & $\begin{array}{c}\text { User- } \\
\text { Reported }\end{array}$ & $\begin{array}{l}\text { Old EPA } \\
\text { Combined }\end{array}$ & $\begin{array}{l}\text { New EPA } \\
\text { Combined }\end{array}$ \\
\hline \multirow[t]{2}{*}{ Ford } & Escape & Escape 2WD V6 & 32 & 34 & 30 & 19 (a) & 22 & 20 \\
\hline & Mariner & Mariner 4WD V6 & 27 & 31 & 27 & $18^{(a)}$ & 21 & 19 \\
\hline \multirow[t]{3}{*}{ GM } & Aura & Aura 3.6L 4-spd Auto & 31 & 30 & 27 & 23 & 24 & 21 \\
\hline & Sierra & GM Sierra 2WD 5.3L & $18^{(a)}$ & 19 & 17 & $13^{(a)}$ & 18 & 16 \\
\hline & Vue & Vue 2WD 6 cyl. Auto & 25 & 29 & 26 & 20 & 23 & 20 \\
\hline \multirow[t]{3}{*}{ Honda } & Accord & Accord 3L Auto. & $22^{(a)}$ & 31 & 27 & 24 & 23 & 21 \\
\hline & Civic & Civic 1.8L Auto. & 43 & 50 & 42 & 28 & 34 & 29 \\
\hline & Insight & Civic 1.8L Auto. & $67^{(\mathrm{a})}$ & 63 & 47 & 28 & 34 & 29 \\
\hline Nissan & Altima & Altima V6 Auto & 34 & 39 & 34 & 25 & 24 & 22 \\
\hline \multirow[t]{6}{*}{ Toyota } & Camry & Camry V6 3.5L Auto. & 36 & 39 & 34 & 24 & 25 & 23 \\
\hline & GS 450h & GS430 & $22^{(b)}$ & 26 & 23 & $18^{(b)}$ & 21 & 19 \\
\hline & Highlander & Highlander 2WD 3.3L & $27^{(a)}$ & 30 & 26 & $20^{(a)}$ & 21 & 19 \\
\hline & LS 600hL & LS $460 \mathrm{~L}$ & $20^{(b)}$ & 23 (c) & 21 & $18^{(b)}$ & 21 & 19 \\
\hline & Prius & Corolla 1.8L Auto. & 45 & 56 & 46 & 31 & 33 & 29 \\
\hline & $\mathrm{RX} 400 \mathrm{~h}$ & $\mathrm{RX} 350$ 2WD & 24 & 30 & 26 & $19^{(b)}$ & 22 & 20 \\
\hline
\end{tabular}

Notes: (a) Fewer than five user-reported samples.

(b) No user-reported samples; $85 \%$ of old EPA combined label value used instead

(c) No published old EPA combined fuel economy available. Approximation used instead. 
The percent improvement in HEV fuel economy over that of a conventional vehicle is listed in Table B-2 for each fuel economy estimate. Regarding these values, note that other vehicle design factors besides hybridization have an impact on fuel economy benefits. These results show a wide range of fuel economy impacts, depending on the HEV design that the manufacturer adopted for the vehicle.

Table B-2. Fuel Economy or Fuel Consumption Benefit

\begin{tabular}{|c|c|c|c|c|c|c|c|c|}
\hline \multirow[b]{2}{*}{ Brand } & \multirow[b]{2}{*}{ Vehicle } & \multirow[b]{2}{*}{ Comparison Vehicle } & \multicolumn{3}{|c|}{ Fuel Economy Improvement } & \multicolumn{3}{|c|}{ Fuel Consumption Decrease } \\
\hline & & & $\begin{array}{c}\text { User- } \\
\text { Reported }\end{array}$ & $\begin{array}{l}\text { Old EPA } \\
\text { Combined }\end{array}$ & $\begin{array}{l}\text { New EPA } \\
\text { Combined }\end{array}$ & $\begin{array}{c}\text { User- } \\
\text { Reported }\end{array}$ & $\begin{array}{l}\text { Old EPA } \\
\text { Combined }\end{array}$ & $\begin{array}{l}\text { New EPA } \\
\text { Combined }\end{array}$ \\
\hline \multirow[t]{2}{*}{ Ford } & Escape & Escape 2WD V6 & $65 \%$ & $55 \%$ & $50 \%$ & $-39 \%$ & $-36 \%$ & $-33 \%$ \\
\hline & Mariner & Mariner 4WD V6 & $53 \%$ & $48 \%$ & $42 \%$ & $-35 \%$ & $-33 \%$ & $-30 \%$ \\
\hline \multirow[t]{3}{*}{ GM } & Aura & Aura 3.6L 4-spd Auto & $34 \%$ & $27 \%$ & $29 \%$ & $-25 \%$ & $-22 \%$ & $-22 \%$ \\
\hline & Sierra & GM Sierra 2WD 5.3L & $31 \%$ & $7 \%$ & $6 \%$ & $-24 \%$ & $-7 \%$ & $-6 \%$ \\
\hline & Vue & Vue 2WD 6 cyl. Auto & $28 \%$ & $27 \%$ & $30 \%$ & $-22 \%$ & $-21 \%$ & $-23 \%$ \\
\hline \multirow[t]{3}{*}{ Honda } & Accord & Accord 3L Auto. & $-9 \%$ & $32 \%$ & $29 \%$ & $10 \%$ & $-24 \%$ & $-22 \%$ \\
\hline & Civic & Civic 1.8L Auto. & $52 \%$ & $48 \%$ & $45 \%$ & $-34 \%$ & $-32 \%$ & $-31 \%$ \\
\hline & Insight & Civic 1.8L Auto. & $138 \%$ & $85 \%$ & $62 \%$ & $-58 \%$ & $-46 \%$ & $-38 \%$ \\
\hline Nissan & Altima & Altima V6 Auto & $35 \%$ & $60 \%$ & $55 \%$ & $-26 \%$ & $-38 \%$ & $-35 \%$ \\
\hline \multirow[t]{6}{*}{ Toyota } & Camry & Camry V6 3.5L Auto. & $53 \%$ & $54 \%$ & $48 \%$ & $-34 \%$ & $-35 \%$ & $-32 \%$ \\
\hline & GS 450h & GS430 & $28 \%$ & $28 \%$ & $21 \%$ & $-22 \%$ & $-22 \%$ & $-17 \%$ \\
\hline & Highlander & Highlander 2WD 3.3L & $38 \%$ & $39 \%$ & $37 \%$ & $-27 \%$ & $-28 \%$ & $-27 \%$ \\
\hline & LS 600hL & LS $460 \mathrm{~L}$ & $10 \%$ & $11 \%$ & $11 \%$ & $-9 \%$ & $-10 \%$ & $-10 \%$ \\
\hline & Prius & Corolla 1.8L Auto. & $47 \%$ & $68 \%$ & $59 \%$ & $-32 \%$ & $-40 \%$ & $-37 \%$ \\
\hline & $\mathrm{RX} 400 \mathrm{~h}$ & RX 350 2WD & $28 \%$ & $34 \%$ & $30 \%$ & $-22 \%$ & $-26 \%$ & $-23 \%$ \\
\hline Average & & & $42 \%$ & $42 \%$ & $37 \%$ & $-27 \%$ & $-28 \%$ & $-26 \%$ \\
\hline
\end{tabular}




\section{Appendix C. Vehicle Fleet Calculation}

$$
V_{i j}=V_{i-1, j-1}\left\{1-\left[\frac{1}{e^{\left.\left(A_{0}+1 \cdot A_{1} \cdot(1-D R A T E)\right)^{j} \cdot S F A C T O R\right)}}\right]\right\},
$$

(Equation C-1)

where

$$
\begin{array}{rll}
V i j & = & \text { number of vehicles in year } i \text { at age } j . \\
i & =\text { year index } \\
j & =\text { age index } \\
\text { DRATE } & =\text { price depreciation rate, set to } 0.13 \\
\text { SFACTOR } & =\text { survival factor, set to } 1.1 \\
A 0 & = & \text { set to } 0.7 \\
A 1 & = & \text { set to } 8.0 .
\end{array}
$$

\begin{tabular}{|c|c|c|c|c|c|c|c|c|c|c|}
\hline Brand & Vehicle & 1999 & 2000 & 2001 & 2002 & 2003 & 2004 & 2005 & 2006 & 2007 \\
\hline \multirow[t]{2}{*}{ Ford } & Escape & & & & & & 2,993 & 21,789 & 41,932 & 63,297 \\
\hline & Mariner & & & & & & & 998 & 4,172 & 7,892 \\
\hline Ford Total & & & & & & & 2,993 & 22,787 & 46,104 & 71,189 \\
\hline \multirow[t]{3}{*}{$\overline{\mathrm{GM}}$} & Aura & & & & & & & & & 772 \\
\hline & Sierra & & & & & & 1,000 & 4,000 & 6,998 & 6,994 \\
\hline & Vue & & & & & & & & & 4,403 \\
\hline GM Total & & & & & & & 1,000 & 4,000 & 6,998 & 12,169 \\
\hline \multirow[t]{3}{*}{ Honda } & Accord & & & & & & 1,061 & 17,887 & 23,480 & 26,871 \\
\hline & Civic & & & & 13,700 & 35,497 & 61,054 & 86,877 & 118,030 & 150,387 \\
\hline & Insight & 17 & 3,805 & 8,530 & 10,743 & 11,933 & 12,496 & 13,120 & 13,761 & 13,623 \\
\hline Honda Total & & 17 & 3,805 & 8,530 & 24,443 & 47,430 & 74,611 & 117,884 & 155,271 & 190,881 \\
\hline Nissan & Altima & & & & & & & & & 8,388 \\
\hline Nissan Total & & & & & & & & & & 8,388 \\
\hline \multirow[t]{6}{*}{ Toyota } & Camry & & & & & & & & 31,341 & 85,811 \\
\hline & GS 450h & & & & & & & & 1,784 & 3,429 \\
\hline & Highlander & & & & & & & 17,989 & 49,470 & 71,503 \\
\hline & LS 600hL & & & & & & & & & 937 \\
\hline & Prius & & 5,562 & 21,117 & 41,228 & 65,805 & 119,736 & 227,491 & 334,146 & 514,722 \\
\hline & RX 400h & & & & & & & 20,674 & 40,830 & 58,103 \\
\hline Toyota Total & & & 5,562 & 21,117 & 41,228 & 65,805 & 119,736 & 266,154 & 457,571 & 734,505 \\
\hline Grand Total & & 17 & 9,367 & 29,647 & 65,671 & 113,235 & 198,340 & 410,825 & 665,944 & $1,017,132$ \\
\hline
\end{tabular}

Source: [47]

Table C-1. HEV Vehicle Stock 


\section{Appendix D. Annual Fuel Savings from New Sales}

$$
G_{i}^{\prime \prime}=S_{i} M_{i}\left[\frac{1}{M P G_{c o n v}}-\frac{1}{M P G_{H E V}}\right],
$$

where

$$
\begin{array}{rll}
G_{i}^{\prime \prime} & = & \text { gallons saved in year } i \\
S_{i} & = & \text { vehicles sold in year } i \\
M_{i} & = & \text { annual VMT in year } i \\
M P G_{c o n v} & = & \text { conventional vehicle fuel economy } \\
M P G_{H E V} & = & \text { HEV fuel economy. }
\end{array}
$$

\begin{tabular}{|c|c|c|c|c|c|c|c|c|c|c|}
\hline Brand & Vehicle & 1999 & 2000 & 2001 & 2002 & 2003 & 2004 & 2005 & 2006 & 2007 \\
\hline \multirow[t]{2}{*}{ Ford } & \multirow{3}{*}{$\begin{array}{l}\text { Escape } \\
\text { Mariner }\end{array}$} & & & & & & \multirow[t]{2}{*}{611} & 3,835 & 4,110 & 4,363 \\
\hline & & & & & & & & 190 & 606 & 710 \\
\hline \multicolumn{6}{|l|}{ Ford Total } & & 611 & 4,025 & 4,716 & 5,073 \\
\hline \multirow[t]{3}{*}{$\overline{\mathrm{GM}}$} & \multirow{4}{*}{$\begin{array}{l}\text { Aura } \\
\text { Sierra } \\
\text { Vue }\end{array}$} & & & & & & \multirow{3}{*}{45} & \multirow{3}{*}{135} & \multirow{3}{*}{135} & 100 \\
\hline & & & & & & & & & & \\
\hline & & & & & & & & & & 622 \\
\hline GM Total & & & & & & & 45 & 135 & 135 & 722 \\
\hline \multirow[t]{3}{*}{ Honda } & \multirow{4}{*}{$\begin{array}{l}\text { Accord } \\
\text { Civic } \\
\text { Insight }\end{array}$} & & & & & & 137 & 2,179 & 725 & 441 \\
\hline & & & & & 1,790 & 2,848 & 3,341 & 3,379 & 4,083 & 4,256 \\
\hline & & 3 & 612 & 764 & 358 & 194 & 94 & 108 & 117 & \\
\hline Honda Total & & 3 & 612 & 764 & 2,148 & 3,042 & 3,572 & 5,666 & 4,925 & 4,697 \\
\hline \multirow{2}{*}{$\begin{array}{l}\text { Nissan } \\
\text { Nissan Total }\end{array}$} & \multirow[t]{2}{*}{ Altima } & & & & & & & & & 1,647 \\
\hline & & & & & & & & & & 1,647 \\
\hline \multirow[t]{6}{*}{ Toyota } & Camry & & & & & & & & 5,396 & 9,380 \\
\hline & GS 450h & & & & & & & & 200 & 184 \\
\hline & \multirow{5}{*}{$\begin{array}{l}\text { Highlander } \\
\text { LS 600hL } \\
\text { Prius } \\
\text { RX 400h }\end{array}$} & & & & & & & 3,120 & 5,461 & 3,825 \\
\hline & & & & & & & & & & 57 \\
\hline & & & 868 & 2,426 & 3,138 & 3,837 & 8,422 & 16,830 & 16,686 & 28,267 \\
\hline & & & & & & & & 2,920 & 2,847 & 2,442 \\
\hline Toyota Total & & & 868 & 2,426 & 3,138 & 3,837 & 8,422 & 22,870 & 30,590 & 44,155 \\
\hline Grand Total & & 3 & 1,480 & 3,190 & 5,286 & 6,879 & 12,650 & 32,696 & 40,366 & 56,294 \\
\hline
\end{tabular}

Table D-1. Fuel Savings from New HEV Sales (thousands of gallons)

Note: $\quad$ Fuel savings based on new EPA labels and 12,240 annual miles. 


\section{Appendix E. Annual Fuel Savings from Vehicle Fleet}

$$
G_{i}^{\prime}=V_{i} M\left[\frac{1}{M P G_{\text {conv }}}-\frac{1}{M P G_{H E V}}\right],
$$

(Equation E-1)

where

$$
\begin{array}{rll}
G_{i}^{\prime} & = & \text { gallons saved in year } i \\
V_{i} & = & \text { total hybrid vehicle stock in year } i \\
M_{i} & = & \text { annual VMT in year } i \\
M P G_{\text {conv }} & = & \text { conventional vehicle fuel economy } \\
M P G_{H E V} & = & \text { HEV fuel economy. }
\end{array}
$$

\begin{tabular}{|c|c|c|c|c|c|c|c|c|c|c|}
\hline Brand & Vehicle & 1999 & 2000 & 2001 & 2002 & 2003 & 2004 & 2005 & 2006 & 2007 \\
\hline \multirow[t]{2}{*}{ Ford } & Escape & & & & & & 611 & 4,445 & 8,554 & 12,913 \\
\hline & Mariner & & & & & & & 190 & 796 & 1,506 \\
\hline Ford Total & & & & & & & 611 & 4,635 & 9,350 & 14,419 \\
\hline \multirow[t]{3}{*}{$\overline{G M}$} & Aura & & & & & & & & & 100 \\
\hline & Sierra & & & & & & 45 & 180 & 315 & 315 \\
\hline & Vue & & & & & & & & & 622 \\
\hline GM Total & & & & & & & 45 & 180 & 315 & 1,037 \\
\hline \multirow[t]{3}{*}{ Honda } & Accord & & & & & & 137 & 2,317 & 3,041 & 3,480 \\
\hline & Civic & & & & 1,790 & 4,637 & 7,976 & 11,350 & 15,419 & 19,647 \\
\hline & Insight & 3 & 615 & 1,379 & 1,737 & 1,929 & 2,020 & 2,121 & 2,224 & 2,202 \\
\hline \multicolumn{2}{|l|}{ Honda Total } & 3 & 615 & 1,379 & 3,527 & 6,566 & 10,133 & 15,788 & 20,684 & 25,329 \\
\hline \multirow{2}{*}{$\begin{array}{l}\text { Nissan } \\
\text { Nissan Total }\end{array}$} & Altima & & & & & & & & & 1,647 \\
\hline & & & & & & & & & & 1,647 \\
\hline \multirow[t]{6}{*}{ Toyota } & Camry & & & & & & & & 5,396 & 14,774 \\
\hline & GS 450h & & & & & & & & 200 & 384 \\
\hline & Highlander & & & & & & & 3,120 & 8,580 & 12,402 \\
\hline & LS 600hL & & & & & & & & & 57 \\
\hline & Prius & & 868 & 3,294 & 6,431 & 10,264 & 18,677 & 35,485 & 52,121 & 80,287 \\
\hline & $\mathrm{RX} 400 \mathrm{~h}$ & & & & & & & 2,920 & 5,766 & 8,206 \\
\hline Toyota Total & & & 868 & 3,294 & 6,431 & 10,264 & 18,677 & 41,525 & 72,063 & 116,110 \\
\hline Grand Total & & 3 & 1,483 & 4,673 & 9,958 & 16,830 & 29,466 & 62,128 & 102,412 & 158,542 \\
\hline
\end{tabular}

Table E-1. Annual HEV Vehicle Stock Fuel Savings (thousands of gallons)

Note: $\quad$ Fuel savings based on new EPA labels and 12,240 annual miles. 


\section{Appendix F. Cumulative Fuel Savings by Year}

$$
G_{j}=\sum_{i=a}^{j} G_{i}^{\prime}
$$

where

$$
\begin{array}{lll}
G_{i}^{\prime} & = & \text { gallons saved in year } i \\
G_{j} & = & \text { total gallons saved between years } a \text { and } j .
\end{array}
$$

\begin{tabular}{|c|c|c|c|c|c|c|c|c|c|c|}
\hline Brand & Vehicle & 1999 & 2000 & 2001 & 2002 & 2003 & 2004 & 2005 & 2006 & 2007 \\
\hline \multirow[t]{2}{*}{ Ford } & Escape & & & & & & 611 & 5,056 & 13,610 & 26,523 \\
\hline & Mariner & & & & & & & 190 & 986 & 2,492 \\
\hline Ford Total & & & & & & & 611 & 5,246 & 14,596 & 29,015 \\
\hline \multirow[t]{3}{*}{$\overline{\mathrm{GM}}$} & Aura & & & & & & & & & 100 \\
\hline & Sierra & & & & & & 45 & 225 & 540 & 855 \\
\hline & Vue & & & & & & & & & 622 \\
\hline GM Total & & & & & & & 45 & 225 & 540 & 1,577 \\
\hline \multirow[t]{3}{*}{ Honda } & Accord & & & & & & 137 & 2,454 & 5,495 & 8,975 \\
\hline & Civic & & & & 1,790 & 6,427 & 14,403 & 25,753 & 41,172 & 60,819 \\
\hline & Insight & 3 & 618 & 1,997 & 3,734 & 5,663 & 7,683 & 9,804 & 12,028 & 14,230 \\
\hline \multicolumn{2}{|l|}{ Honda Total } & 3 & 618 & 1,997 & 5,524 & 12,090 & 22,223 & 38,011 & 58,695 & 84,024 \\
\hline \multirow{2}{*}{$\begin{array}{l}\text { Nissan } \\
\text { Nissan Total }\end{array}$} & Altima & & & & & & & & & 1,647 \\
\hline & & & & & & & & & & 1,647 \\
\hline \multirow[t]{6}{*}{ Toyota } & Camry & & & & & & & & 5,396 & 20,170 \\
\hline & GS 450h & & & & & & & & 200 & 584 \\
\hline & Highlander & & & & & & & 3,120 & 11,700 & 24,102 \\
\hline & LS $600 \mathrm{hL}$ & & & & & & & & & 57 \\
\hline & Prius & & 868 & 4,162 & 10,593 & 20,857 & 39,534 & 75,019 & 127,140 & 207,427 \\
\hline & $\mathrm{RX} 400 \mathrm{~h}$ & & & & & & & 2,920 & 8,686 & 16,892 \\
\hline Toyota Total & & & 868 & 4,162 & 10,593 & 20,857 & 39,534 & 81,059 & 153,122 & 269,232 \\
\hline Grand Total & & 3 & 1,486 & 6,159 & 16,117 & 32,947 & 62,413 & 124,541 & 226,953 & 385,495 \\
\hline
\end{tabular}

Table F-1. Cumulative HEV Fuel Savings (thousands of gallons)

Note: $\quad$ Fuel savings based on new EPA labels and 12,240 annual miles. 


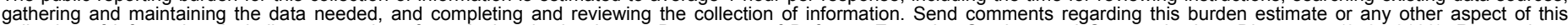

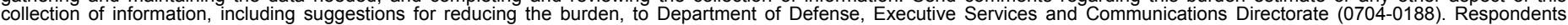

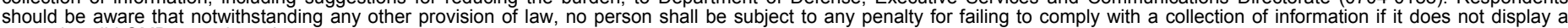

should be aware that notwithstanding

PLEASE DO NOT RETURN YOUR FORM TO THE ABOVE ORGANIZATION.

\section{REPORT DATE (DD-MM-YYYY) March 2009 \\ 2. REPORT TYPE \\ Technical Report}

4. TITLE AND SUBTITLE

Fuel Savings from Hybrid Electric Vehicles
3. DATES COVERED (From - To) 5a. CONTRACT NUMBER

DE-AC36-08-GO28308

5b. GRANT NUMBER

5c. PROGRAM ELEMENT NUMBER
6. AUTHOR(S)

K. Bennion and M. Thornton 5d. PROJECT NUMBER

NREL/TP-540-42681

5e. TASK NUMBER

FC08.2000

5f. WORK UNIT NUMBER
7. PERFORMING ORGANIZATION NAME(S) AND ADDRESS(ES)

National Renewable Energy Laboratory

1617 Cole Blvd.

Golden, CO 80401-3393
8. PERFORMING ORGANIZATION REPORT NUMBER

NREL/TP-540-42681

9. SPONSORING/MONITORING AGENCY NAME(S) AND ADDRESS(ES)

10. SPONSOR/MONITOR'S ACRONYM(S) NREL

11. SPONSORING/MONITORING AGENCY REPORT NUMBER

12. DISTRIBUTION AVAILABILITY STATEMENT

National Technical Information Service

U.S. Department of Commerce

5285 Port Royal Road

Springfield, VA 22161

\section{SUPPLEMENTARY NOTES}

14. ABSTRACT (Maximum 200 Words)

Since they were introduced in the United States in 1999, hybrid electric vehicles (HEVs) have saved nearly 230 million gallons (5.5 million barrels) of fuel. The National Renewable Energy Laboratory (NREL) calculated the fuel savings resulting from using HEVs by comparing their fuel use with that of similar conventional vehicles, which closely matched the hybrid as to size, weight, performance, and vehicle manufacturer. NREL estimated the total HEVs in use for a given year (vehicle stock) using available sales data and Argonne National Laboratory's VISION model. Though fuel savings are small in relation to the total amount used in light-duty U.S. vehicles, this is a big step forward in reducing imported fuel for U.S. transportation needs and improving vehicle efficiency. Hybrid electric vehicles represent a small but growing group of vehicles in the United States. Applying hybrid technology to large cars, minivans, sport utility vehicles, and light-duty trucks will help to increase fuel savings from HEVs.

\section{SUBJECT TERMS}

fuel economy; fuel savings; hybrid vehicles; hybrid electric vehicles; hybrid electric vehicle sales; HEVs

\begin{tabular}{|c|c|c|c|c|}
\hline \multicolumn{3}{|c|}{ 16. SECURITY CLASSIFICATION OF: } & \multirow{2}{*}{$\begin{array}{l}\text { 17. LIMITATION } \\
\text { OF ABSTRACT } \\
\text { UL }\end{array}$} & \multirow{2}{*}{$\begin{array}{ll}\text { 18. } & \text { NUMBER } \\
\text { OF PAGES }\end{array}$} \\
\hline $\begin{array}{l}\text { a. REPORT } \\
\text { Unclassified }\end{array}$ & $\begin{array}{l}\text { b. ABSTRACT } \\
\text { Unclassified }\end{array}$ & $\begin{array}{l}\text { c. THIS PAGE } \\
\text { Unclassified }\end{array}$ & & \\
\hline
\end{tabular}

19a. NAME OF RESPONSIBLE PERSON
19b. TELEPHONE NUMBER (Include area code)

